\title{
Major and Trace Elements Geochemistry of the Selenga River, Transbaikalia
}

\author{
Zinaida Ivanovna Khazheeva, Aleksey Maksimovich Plyusnin and Viktoriya Valerievna \\ Dabaeva *
}

Geological Institute of SB RAS, Ulan-Ude, zkhazh@geo.stbur.ru (Z.I.K.)

* Correspondence: dv.viktoriya@geo.stbur.ru (D.V.V.)

\begin{abstract}
Selenge River is a transboundary river, which rises in the Khanghai Mountains in Mongolia and flows into the Lake Baikal in the Republic of Buryatia (Russia). We studied the Selenga River basin (446 $000 \mathrm{~km}^{2}$ ) located in western Siberia (Transbaikalia, Russia), and northern and central Mongolia between the Tuva-Mongol and Dzabkhan microcontinents in the west, the Siberia craton in the north and the Amurian superterrane in the south. Water resources are very limited in this basin because annual precipitation is only $250-400 \mathrm{~mm}$. Moreover, $90 \%$ of annual precipitation occurs in summer, which causes frequent flooding in summer and severe shortage of water during the rest of the year. The transition from a planned economy to a market economy has resulted in inefficiently operated wastewater treatment systems which pollute the river, and reckless deforestation have increased non-point pollution sources on the lower Selenge River in Russia. Recent years, in the structure of industrial water consumption than $50 \%$ of withdrawn water was used by the mining industry in Mongolia. The mining enterprises are located in watershed of small tributaries the second order of the Selenge River. In this work we present current state of the Selenge River chemistry and estimate heavy metal pollution. From 2004, the requirement of federal law of Russia «On the protection of lake Baikal» the new variant of regional norms MAC (Maximum Allowable Concentration) were elaborated. The concentration of the main polluting substances were compared with norms MAC.
\end{abstract}

The dissolved concentrations of major, trees elements, and REE, dissolved organic carbon (DOC) have been measured in Selenge River draining watersheds with various surface areas. Measured $\mathrm{pH}$ for all sampling sites were within the standard range for river water, which is between 6 and 9 , meantime had the highest measured $\mathrm{pH} 9.2$ that may be due to anthropogenic impact. The total dissolved load (TDS) is 108-297 $\mathrm{mg} \mathrm{l}^{-1}$. Mongolian and Russian part of Selenge River having different drainage areas and hydrological parameters were sampled over a 6-year period. Collected data show that the river present the same monthly seasonal variations, with higher concentrations in winter and lower concentrations during other seasons. In waters, DOC and insoluble element concentrations (e.g., $\mathrm{Al}, \mathrm{Fe}$, and $\mathrm{Th}$ ) were strongly correlated which show the key role of organic colloidal matter in the transport of some insoluble elements.

Keywords: transboundary river; major and trace elements; pollution; maximum allowable concentration; organic matter; insoluble element

\section{Introduction}

The international basin of the Selenge River is situated in the center of Eurasia, close to the watershed of Pacific Oceans and the basin of Central Asia. The Selenge River Basin is located in the area of contact with the taiga and steppe zones. This area is characterized by a high level of biodiversity and high sensitivity to external impact (Fig.1). 


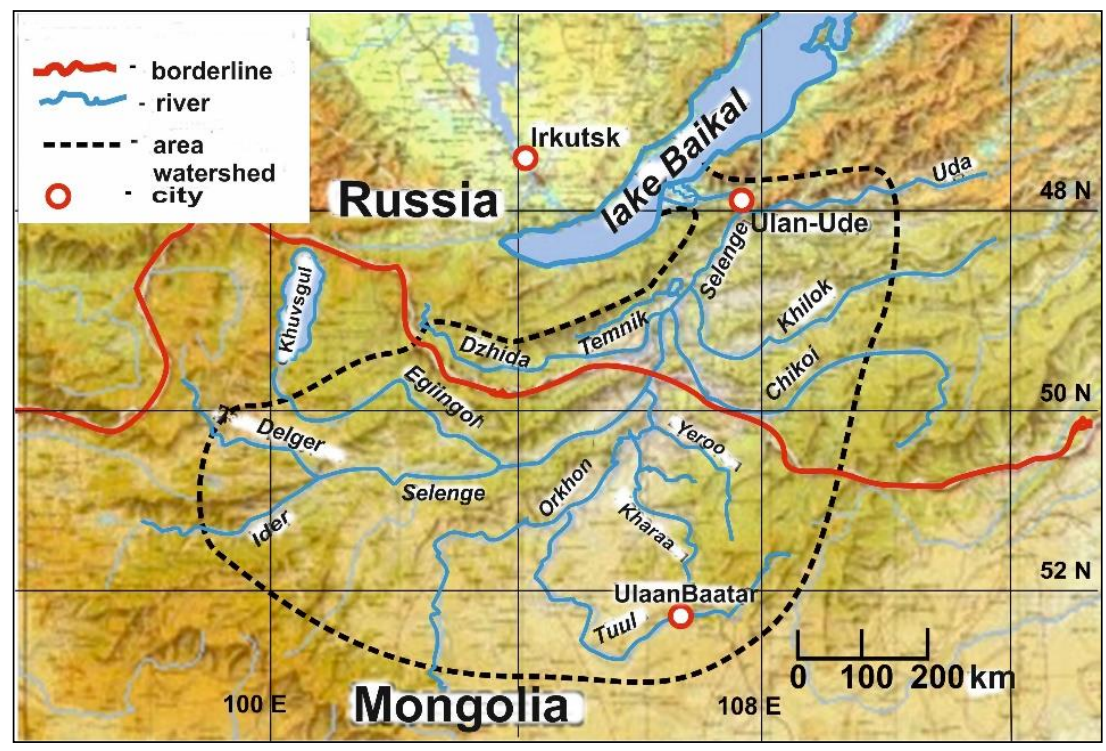

Figure 1. The map of Selenge River basin.

The river was formed after the confluence of the rivers Delger and Ider. Crossing the uplands of the Northern Khalka in the north-eastern direction, the Selenge River turns north at the Orkhon River and accumulating the waters of its many tributaries flows into Lake Baikal. At inflow it forms a unique freshwater delta with the total area of $600 \mathrm{~km}^{2}$, which is considered a water-swampy area of international significance (object of the Ramsar convention from 1975).

The interstate borders divide the Selenge River basin into two unequal parts: upper part is in Mongolia and the lower part with prevailing water is within the Russian Federation. The lower part belongs to Baikal natural territory, within which the special regime of economic activity was established by the Russian legislation. In Mongolia environmental requirements for the use of natural resources in the upper part of the basin did not identify.

The Mongolian part of the basin occupies $19,2 \%$ of the territory, includes $70 \%$ of the population, and accounts for $80 \%$ of industrial and $60 \%$ of agricultural production. Today the population and industries are concentrated in the central region that are a considerable load on the environment. The expected social-economic breakthrough in Mongolia is entirely connected with the development of the resources of the central region. Nowadays there are a number of big foreign companies, including Russian ones, getting ready to start work on the unique deposits. For example, investments in production capacities through joint enterprises «Erdenet», «Mongol Rostsvetmet» produce $50 \%$ of Mongolia exports. The development of natural resources is closely connected with the joint projects of the development of energy, machine-building, transport infrastructure. Thus, the upper flow the Selenge River crosses the central region of Mongolia which is comprised of powerful sources of industrial pollution, connected with enterprises for the production of gold, copper, molybdenum, non-ferrous, rare, precious metals, brown coal, and other minerals. Mining enterprises are located in the cities of Bulgan, Darkhan, Muren, Ulaanbaatar, Sharingol and Erdenet. This cities are situated on the tributaries Selenge River of second order - Tuul, Kharaa, Khangal, Sharingol.

The present problems of water use in the Selenge River basin are rather acute in Mongolia. This is connected with the disproportion of territorial distribution of the river flow and water consumers, rapid growth of demand for water, limitedness of the underground water reserves, abrupt seasonal variations of the river flow, weak ability for self-purification of the flow, high natural concentration of some microelements. The total amount of water intake for the Mongolian portion of the Selenge River Basin in 2004 was 495.2 million $\mathrm{m}^{3}$ and increased in comparison with 1990 by 1.5 times due to the growth of industrial water consumption more than $50 \%$ of withdrawn water was used by mining industry. For agriculture, practically the whole amount of withdrawn water is used for irrigation, 
which requires more than 70 million $\mathrm{m}^{3}$. The level of the water economy in industry due to the circulating water supply is not high and is equal to less than $40 \%$.

In Russian part of the Selenge River Basin water intake in 2004 was 424.1 million $\mathrm{m}^{3}$ and reduced in comparison with 1990 more than twice, including industry (with energy generation) by 1.5 times, and agriculture by 3.7 times (irrigated agriculture by 4.2 times). A slight growth in the amount of water consumption (in 1.2 times) was observed in housing-communal services. Industry remained the largest water consumer, accounting for $65.5 \%$ of the total water intake. The reduction of the amount of water consumption conditioned a twofold decrease of the amount of discharged water. In the Russian part of the Selenge River Basin the industrial enterprises of Ulan-Ude were dumped in river. Of the total amount of discharged water, more than $20 \%$ belonged to the category of polluted.

The total amount of water withdrawal in 2004 was 919.3 million $\mathrm{m}^{3}$ from which $70 \%$ of water withdrawn from surface water objects. The amount of water, dumped into the river network, was 660.9 million $\mathrm{m}^{3}$ which enabled to regenerate the resources of surface water in separate sections of the Russian part. The total amount of the used water flow in 2004 was equal to $2 \%$ of the average long-term period, including irrevocably less than $1 \%$ [1-3].

\subsection{Geology}

Selenga River basin $\left(446,000 \mathrm{~km}^{2}\right)$ located in western Siberia (Transbaikalia), and northern and central Mongolia between the Tuva-Mongol and Dzabkhan microcontinents in the west, the Siberia craton in the north and the Amurian superterrane in the south [4]. The majority of Late Paleozoic Mesozoic igneous and volcanic rocks in the southern margin of the Siberian continent are located in eastern Siberia (Transbaikalia, Russia), and northern and central Mongolia between the Tuva-Mongol and Dzabkhan microcontinents in the west, the Siberian craton in the north and the Amurian superterrane in the south (Fig.2).

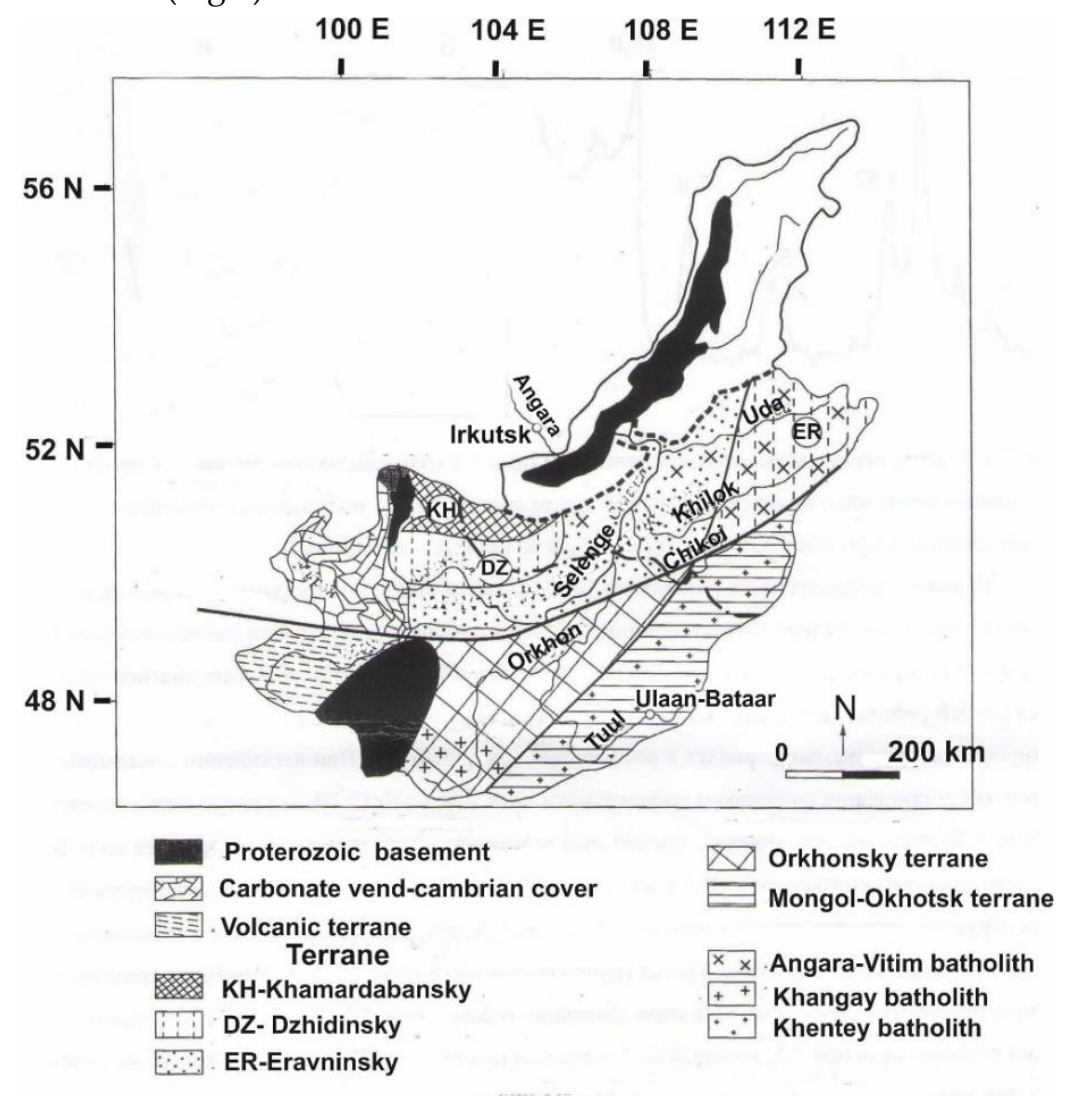

Figure 2. Simplified tectonic map of the Central Asian Orogenic Belt (compiled and modified from [5]. 
The Mongol-Okhotsk Ocean was an embayment of the Paleo- Pacific, which existed in the Late Paleozoic - Early Mesozoic between the Siberian and Mongolia-North China continents. Numerous intrusions as well as voluminous lavas are located northward from the Mongol-Okhotsk suture and formed before the closure of the Mongol-Okhotsk Ocean.

Relicts of this large ocean remain as fragments of metamorphosed sediments and volcanics within the Mongol-Okhotsk orogenic belt/suture, which formed during its closure. The MongolOkhotsk orogenic (fold) belt is the youngest segment of the Central Asian Orogenic Belt (CAOB), which is one of the largest accretionary complexes on the Earth. The CAOB or Altaids [6] is located between the Siberian craton in the north, and the North China and Tarim cratons in the south [7]. It was formed by collision of the Siberian and North China cratons and consists of relicts of island arcs, oceanic islands, ophiolites, back-arc basins, accretionary wedges, Precambrian microcontinents and superterranes (Fig. 2).

There are a few different points of view on the geodynamic setting of formation of the Late Paleozoic - Late Mesozoic granitoid batholiths and volcanoplutonic belts in eastern Siberia (Transbaikalia, Russia), and northern and central Mongolia, including the Angara-Vitim, Khangay and Khentey batholiths, in the Western Transbaikalian, Northern Mongolia and MongolianTransbaikalian belts.

Granitoids of the Angara-Vitim batholith, magmatic intrusions and lavas of the Western Transbaikalian belt were emplaced at an early stage of evolution of the Siberian active continental margin, in the Carboniferous to Early Permian [4]

The Angara-Vitim batholith occupies an area more than 150,000 km2 (Fig. 2). The western part of the batholith is located to the north of the Khentey turbidite basin of the Mongol-Okhotsk Ocean, and its eastern part is situated near to Mongol-Okhotsk suture.

The Angara-Vitim batholith granitoids developed on heterogeneous basement. They intrude rocks of the Siberian craton, terranes which accreted to the craton in Early Paleozoic, as well as the Middle Devonian-Early Carboniferous sedimentary strata of the Tocher trough. U-Pb zircon ages of the Angara-Vitim batholith granitoids vary from $333 \pm 10 \mathrm{Ma}$ to $278.5 \pm 2.4 \mathrm{Ma}$. The Angara-Vitim batholith comprises granodiorites, biotite granites, leucogranites, monzonites, quartz syenites and syenites belong to calc-alkaline series [8].

The Khangay batholith granitoids belong to calc-alkaline series, and demonstrate I-type geochemical affinities [9]. These granitoids are close to amphibole-bearing calc-alkaline granitoids. It is generally interpreted that such granitoids develop along active continental margin above a subduction zone. The Khangay batholith is located on the northern side of the Mongol-Okhotsk suture and occupies area about $120000 \mathrm{~km} 2$ (Fig.2). U-Pb zircon ages of the Khangay batholith granitoids vary from $261.0 \pm 3 \mathrm{Ma}$ to $241.3 \pm 1.5 \mathrm{Ma}$ [10].

The Khentey batholith is the largest Late Triassic magmatic unit of northern and central Mongolia. This batholith is located east of the Khangay batholith (Fig. 2). The granitoids of the Khentey batholith intrude Devonian and Carboniferous turbidites of the Khentey basin, and Ediacaran and Cambrian rocks of the terranes which accreted to the Siberian craton in Early Paleozoic. U-Pb zircon ages of the Khentey batholith granites vary from 207.0 $\pm 6.8 \mathrm{Ma}$ to $227 \pm 8 \mathrm{Ma}$ [11].

The Khentey batholith, similar to the Khangay batholith, contains calc-alkaline granodiorites and granites; gabbros, diorites, plagiogranites, tonalites-trondhjemites and leucogranites are subordinate. The majority of the Khentey batholith granitoids belong to the calc-alkaline series. According to [12] criteria the granitoids of the Khentey batholith are close to amphibole-bearing calcalkaline granitoids of active continental margins.

\subsection{Climate}

Seasonal and annual distribution of water resources is changing due to climate change impacts. Melting of high mountain glaciers has increased Uvs and Khyargas lake levels by 1-2 m during the last 40 years. In the meantime, water levels in other lakes and runoff from rivers in some areas where there is not sufficient input from glaciers has been decreasing [1]. Global climate change have 
occurred in Transbaikalia. Annual precipitation is only $210-360 \mathrm{~mm}$. The intensity of warming are $0.81^{\circ} \mathrm{C} / 30$ years. Seasonally, an increase in temperature is more noticeable in the cold period (winter, autumn). In the forest-steppe and steppe zones it is observed a decrease or small increase of annual precipitation. The runoff of Selenge River is decreased from 24 to 39\% in the period 2000-2010 [13]. The desert steppe zones will be affected by desertification. Vegetation zones will shift further northward, reducing forest cover and fertile alpin vegetation.

\section{Materials and Methods}

\subsection{Sampling site}

The map in Fig. 3 shows the sampling point locations within the Selenge River basin. A total of 760 samples of water and suspended materials were collected at sites S1-S12. Information about samples and its location is given in Table 1 . Surface water $(0-0.5 \mathrm{~m})$ were collected in 2004-2012 during the low water level. Up to 2000 year the average annual flow of river Selenge according to Buryat Center for Hydrometeorology was $32,5 \mathrm{~km}^{3}$. A hydrological regime for the Selenge River from the Mongolian border to the inflow into Lake Baikal is characterized with fluctuations of discharge from $30 \mathrm{~m}^{3} / \mathrm{sec}$ during the winter low-water period to $7620 \mathrm{~m}^{3} / \mathrm{sec}$ during the summer flooding period.

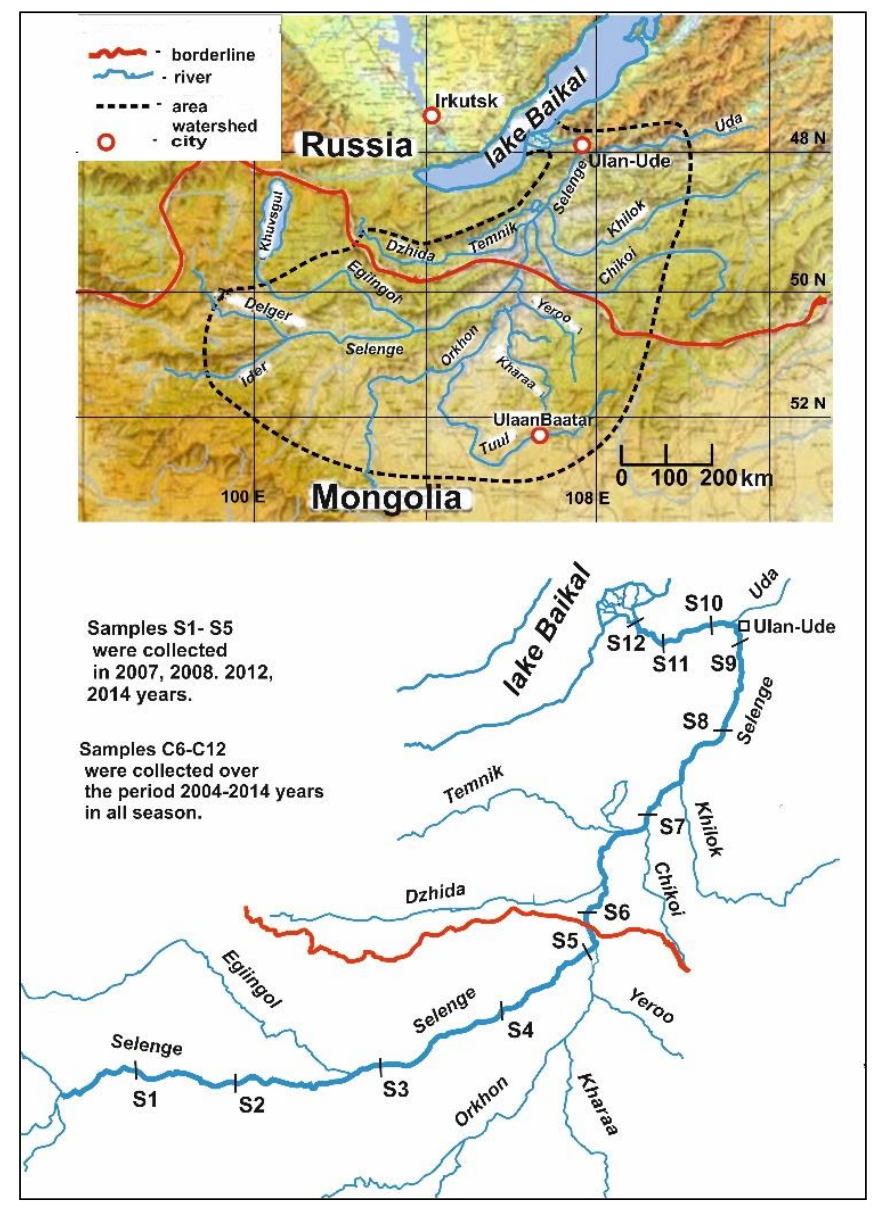

Figure 3. The map of sampling points in the Selenge River.

With intensified global warming in Transbaikalia and north of Mongolia climatic changes are accompanied an increase in temperature, and a decrease in precipitation in steppe zones. Affected by temperature and precipitation variation, the period 1996-2011 are the low-water level for Selenge River. For example, the runoff of Selenge River had decreased up to $16.8 \mathrm{~km}^{3}$, discharge in summer - up to $1200-1600 \mathrm{~m}^{3} / \mathrm{sec}$ in 2007 year. In Russia after inflow tributaries Dzhida, Chikoi, Temnik, 
Khilik, Uda the discharge of Selenge River in downstream increase by 2.6-3 times than at the interstate border, as shown in Fig. 4.

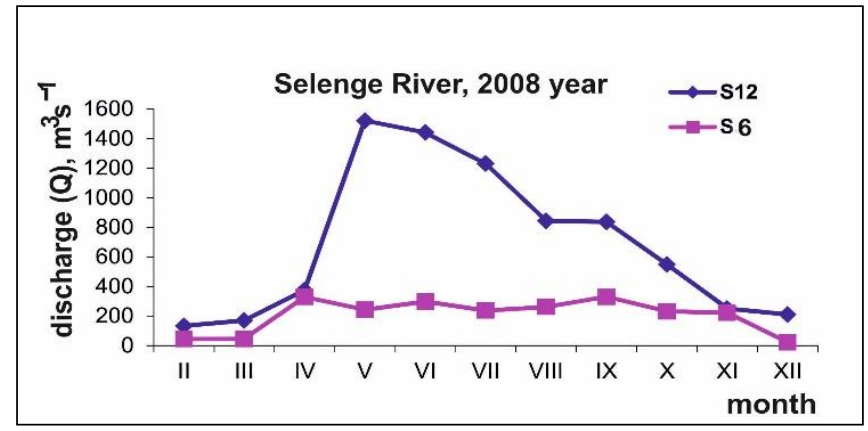

Figure 4. Comparison discharge at the sampling points in interstate border and downstream in Russia.

Table 1. Sampling site and their location along r. Selenge.

\begin{tabular}{|c|c|c|}
\hline Sample site & GPS & Location \\
\hline \multicolumn{3}{|c|}{ In Mongolia } \\
\hline \multirow{2}{*}{ S1 } & $\mathrm{N} 49^{\circ} 56^{\prime} 31^{\prime \prime}$ & Beginning \\
\hline & $\mathrm{E} 101^{\mathrm{O}} 29^{\prime} 58^{\prime \prime}$ & Selenge \\
\hline \multirow{2}{*}{ S2 } & $\mathrm{N} 49^{\circ} 36^{\prime} 18^{\prime \prime}$ & \multirow{2}{*}{ Ikh-Uul } \\
\hline & $\mathrm{E} 101^{\circ} 42^{\prime} 39^{\prime \prime}$ & \\
\hline \multirow{2}{*}{ S3 } & N49 $32^{\prime} 11^{\prime \prime}$ & \multirow{2}{*}{ Hutag-Under } \\
\hline & $\mathrm{E} 102^{\circ} 48^{\prime} 19^{\prime \prime}$ & \\
\hline \multirow{2}{*}{ S4 } & $\mathrm{N} 49^{\circ} 45^{\prime} 12^{\prime \prime}$ & \multirow{2}{*}{ Selenge } \\
\hline & $\mathrm{E} 104^{\mathrm{O}} 07^{\prime} 19^{\prime \prime}$ & \\
\hline \multirow{2}{*}{ S5 } & N5012'11" & \multirow{2}{*}{ Before r. Orkhon } \\
\hline & $\mathrm{E} 105^{\circ} 57^{\prime} 48^{\prime \prime}$ & \\
\hline \multicolumn{3}{|r|}{ In Russia } \\
\hline \multirow{2}{*}{ S6 } & $\mathrm{N} 50^{\circ} 23^{\prime} 01^{\prime \prime}$ & \multirow[t]{2}{*}{ Naushki } \\
\hline & $\mathrm{E} 106^{\circ} 04^{\prime} 51^{\prime \prime}$ & \\
\hline \multirow{2}{*}{ S7 } & $\mathrm{N} 51^{\circ} 02^{\prime} 32^{\prime \prime}$ & \multirow{2}{*}{ After inflow r. Dzhida and r. Chikoi } \\
\hline & $\mathrm{E} 106^{\circ} 39^{\prime} 17^{\prime \prime}$ & \\
\hline \multirow{2}{*}{ S8 } & $\mathrm{N} 51^{\circ} 18^{\prime} 56^{\prime \prime}$ & \multirow{2}{*}{ After inflow r. Temnik and r. Chilok } \\
\hline & $\mathrm{E} 106^{\circ} 59^{\prime} 20^{\prime \prime}$ & \\
\hline \multirow{2}{*}{ S9 } & $\mathrm{N} 51^{\circ} 38^{\prime} 42^{\prime \prime}$ & \multirow{2}{*}{ Upstream of the sity Ulan-Ude } \\
\hline & $\mathrm{E} 107^{\circ} 21^{\prime} 49^{\prime \prime}$ & \\
\hline \multirow{2}{*}{ S10 } & $\mathrm{N} 51^{\circ} 49^{\prime} 07^{\prime \prime}$ & \multirow{2}{*}{ Downstream of the sity Ulan-Ude } \\
\hline & $\mathrm{E} 107^{\circ} 33^{\prime} 19^{\prime \prime}$ & \\
\hline \multirow{2}{*}{ S11 } & $\mathrm{N} 52^{\circ} 02^{\prime} 12^{\prime \prime}$ & \multirow{2}{*}{ Treskovo } \\
\hline & $\mathrm{E} 106^{\circ} 48^{\prime} 49^{\prime \prime}$ & \\
\hline \multirow{2}{*}{ S12 } & $\mathrm{N} 52^{\circ} 06^{\prime} 34^{\prime \prime}$ & \multirow{2}{*}{ Kabansk } \\
\hline & $\mathrm{E} 106^{\circ} 37^{\prime} 44^{\prime \prime}$ & \\
\hline
\end{tabular}

\subsection{Sample analyses}

The water samples were immediately preserved in $1 \mathrm{~L}$ polypropylene sampling bottles at $4^{\circ} \mathrm{C}$ in darkness and analyzed within $48 \mathrm{~h}$. The samples were filtrated by $0.45 \mu \mathrm{m}$ filter and divided into soluble water samples and insoluble (particle samples) for $\mathrm{Fe}, \mathrm{Mn}, \mathrm{Pb}, \mathrm{Cu}, \mathrm{Zn}, \mathrm{As}, \mathrm{Cd}$ analysis. Filtrate samples were digested by with of $\mathrm{HNO}_{3}$ up $\mathrm{pH} 2$ then was used for determination of 
dissolved heavy trace elements and REE. The parameters of water quality included suspended solids (SS), conductivity (Cond), dissolved oxygen (DO), $\mathrm{pH}$, chemical oxygen demand (COD), biologic oxygen demand (BOD), total nitrogen $(\mathrm{TN})$, ammonium nitrogen $\left(\mathrm{NH}_{4}-\mathrm{N}\right)$, total phosphates (TP), petroleum (Petro) and volatile phenolics (V-phen). The $\mathrm{pH}$, conductivity, and DO were determined directly at each sampling site. The conductivity was measured with YSI meter Model 33 (YSI, USA), the $\mathrm{pH}$ was measured by a $\mathrm{pH}$ meter Beckman Model F8253 (Beckman, USA), and the DO was measured by a YSI oxygen meter Model 57 (YSI, USA).

The water analyzed in the water analysis laboratory of the Geological Institute Siberian Branch of Russian Academy of Sciences (GIN SB RAS). Water quality parameters were determined by the following methods: $\mathrm{Ca}^{2+}, \mathrm{Mg}^{2+}$ - complexonometry, $\mathrm{Na}^{+}+\mathrm{K}^{+}$- flame-photometer of M7D type, $\mathrm{CO}_{3}^{2-}$, $\mathrm{HCO}_{3-}^{-}$-volumetric, $\mathrm{Cl}^{-}$-argentometry, $\mathrm{SO}_{4}^{2-}$ - weight, oxidation of permanganate - permanganate. Major cations of water samples collected in 2008 year were determined with another ion chromatograph (ICS-2500, Dinex) and major anions except $\mathrm{HCO}_{3}{ }^{-}$were measured by ICS-2000. $\mathrm{HCO}^{-}$ concentration was estimated from the ion balance of major cations and anions. Trace elements and REE was measured using inductively coupled plasma mass spectrometry (ELEMENT XR, Thermo Finigan, Germany), insoluble heavy metals was measured using atomic adsorption spectrophotometer AAC Pin AAcle 900F at the «Analytical center of mineralogical, geochemical and isotope studies» of the Geological Institute of the Siberian Branch of the Russian Academy of Sciences (Ulan-Ude, Russia). The SS, COD, BOD, TN, TP, $\mathrm{NH}_{4}-\mathrm{N}$ were determined using standard methods. Petro was measured using Infrared Spectrophotometry, and V-pen was measured using Flow Injection- Spectrophotometry.

\section{RESULTS AND DISCUSSION}

\subsection{Main ions and total dissolved solids (TDS)}

Long-term on the average ionic composition of water are presented in Table 2. There are considerable natural variability in measured water parameters $\mathrm{pH}$, ion composition and mineralization, nitrogen and organic carbon concentrations in the dissolved load are associated to water discharge.

Table 2. Chemical composition of Selenga river water in summer 2004-2012 (mean value),mg l-1.

\begin{tabular}{ccccccccccccc}
\hline $\begin{array}{c}\text { Sample } \\
\text { point }\end{array}$ & S1 & S2 & S3 & S4 & S5 & S6 & S7 & S8 & S9 & S10 & S11 & S12 \\
\hline $\mathrm{pH}$ & 8.12 & 8.08 & 8.64 & 8.22 & 8.34 & 8.36 & 8.26 & 8.34 & 8.19 & 8.32 & 8.36 & 8.41 \\
\hline $\mathrm{HCO}^{-}$ & 119 & 121 & 125 & 117 & 128 & 124 & 114 & 109 & 106 & 98.7 & 96.3 & 95.8 \\
\hline $\mathrm{SO}_{4}{ }^{2-}$ & 14.5 & 14.3 & 13.8 & 15.2 & 14.2 & 15.7 & 13.8 & 12.7 & 11.8 & 13.4 & 12.9 & 12.4 \\
\hline $\mathrm{Cl}^{-}$ & 2.7 & 3.4 & 3.8 & 4.3 & 3.7 & 2.8 & 2.6 & 2.9 & 2.6 & 2.4 & 2.5 & 2.7 \\
\hline $\mathrm{Ca}^{2+}$ & 52.4 & 42.7 & 53.4 & 45.2 & 51.8 & 36.6 & 29.7 & 28.4 & 27.3 & 26.8 & 25.6 & 24.4 \\
\hline $\mathrm{Mg}^{2+}$ & 9.6 & 8.3 & 11.8 & 9.5 & 9.8 & 7.6 & 6.5 & 5.8 & 5.9 & 6.2 & 6.6 & 6.7 \\
\hline $\mathrm{Na}^{+}+\mathrm{K}^{+}$ & 12.8 & 13.4 & 13.6 & 11.2 & 9.6 & 7.8 & 8.2 & 7.6 & 8.1 & 6.8 & 7.2 & 6.6 \\
\hline $\mathrm{F}-$ & 0.34 & 0.42 & 0.37 & 0.45 & 0.46 & 0.54 & 0.49 & 0.57 & 0.46 & 0.53 & 0.56 & 0.59 \\
\hline${ }^{*} \mathrm{M}$ & 191.5 & 195.1 & 200 & 191.3 & 198.7 & 192.8 & 178.8 & 170.7 & 165.8 & 158.6 & 155.6 & 152.8 \\
\hline $\mathrm{Si}$ & 4.2 & 4.6 & 5.2 & 4.4 & 4.1 & 3.8 & 3.5 & 3.7 & 3.6 & 3.8 & 3.9 & 3.6 \\
\hline $\mathrm{NO}_{3}{ }^{-}$ & 0.03 & 0.04 & 0.02 & 0.05 & 0.04 & 0.02 & 0.03 & 0.02 & 0.05 & 0.03 & 0.04 & 0.03 \\
\hline $\mathrm{COD}^{15.8}$ & 15.5 & 14.6 & 13.8 & 14.9 & 15.3 & 13.7 & 12.6 & 13.1 & 12.8 & 13.6 & 15.6 \\
\hline & & & & & $* M-M i n e r a l i z a t i o n$. & & & & &
\end{tabular}

Concentrations of hydrogen ions vary generally in the range of 6.5-8.9. In winter, $\mathrm{pH}$ values are 6.7-7.4, whereas in summer $\mathrm{pH}$ values are 7.3-8.9. In general, the $\mathrm{pH}$ regime is similar to that of $\mathrm{CO}_{2}$. At the upstream in Mongolia where carbonate rock is dominant $\mathrm{pH}$ values exceed 8.0.

During winter low-flow these waters are characterized by high mineralization usually 220-325 $\mathrm{mg} \mathrm{l}^{-1}$. During period of spring flood, concentrations of major ions are significantly lower (Fig.5), 
mineral content ranges between 95-180 $\mathrm{mg} \mathrm{l}^{-1}$. In summer and autumn the total ion concentration varies between $110-220 \mathrm{mg} \mathrm{l}^{-1}$. Plotted in Fig. is the discharge vs. mineralization at the sampling sites S6 and S12. In this figure we show for comparison variations of discharge and mineralization along the river flow from Mongolia to Russia and its seasonal fluctuations. There is an increase mineralization in Mongolia part of river. In the Mongolia territory climate aridity increases, precipitation decreases, discharge of water flow small, sometimes saline soils enrich the water with minerals. In Russia discharge of water increase by 2-3 times, that leads to the formation of lowly mineralized water. Mean intra-annually mineralization decrease from 200 to $152.8 \mathrm{mg} \mathrm{l}^{-1}$ between upstream in Mongolia and downstream in Russia.
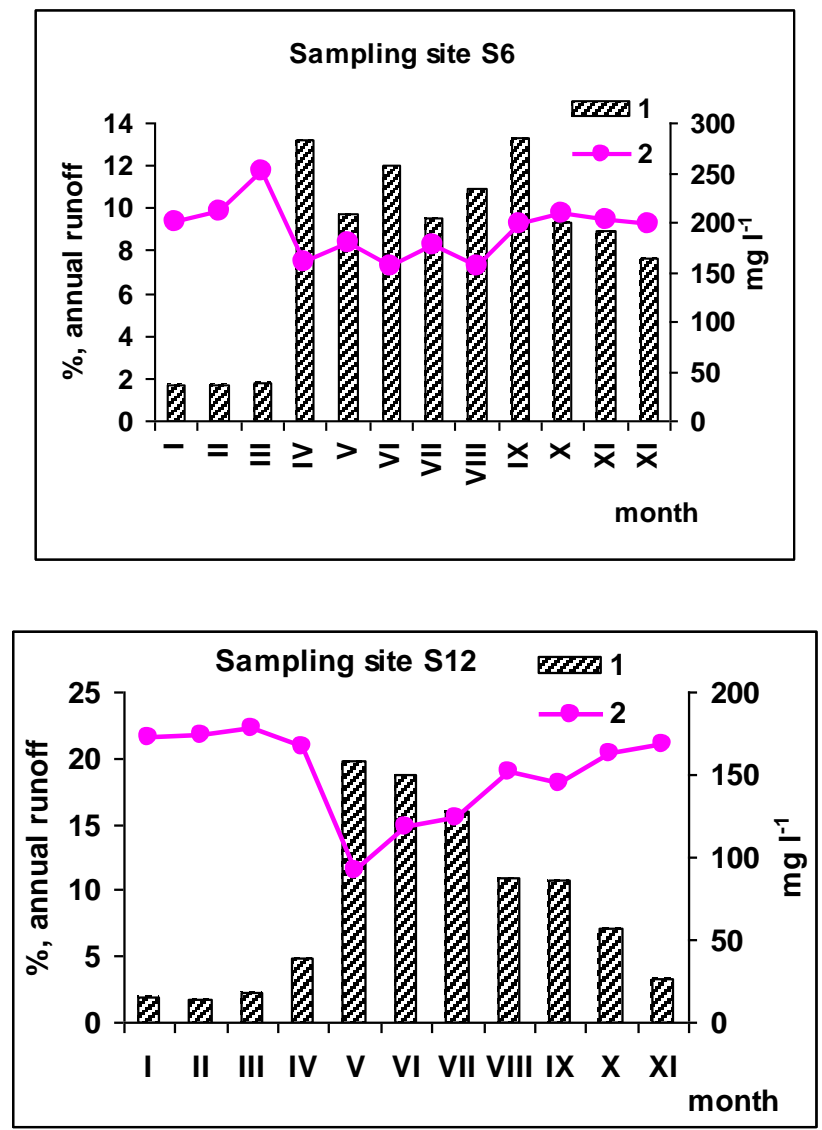

Figure 5. Mineralization vs. annual runoff at the sampling sites S6 and S12.

Along the Selenge River there is natural variability of water of ion composition. The major cations are in decreasing order as $\mathrm{Ca}^{2+}>\mathrm{Mg}^{2+}>\mathrm{Na}^{+}+\mathrm{K}^{+}$and major anions are also in decreasing order as $\mathrm{HCO}_{3}^{-}>\mathrm{SO}_{4} 2^{2-}>\mathrm{Cl}$. The relative abundance of cations with the equiv. $\%$ of $\mathrm{Na}^{+}, \mathrm{K}^{+}, \mathrm{Ca}^{2+}$, and $\mathrm{Mg}^{2+}$ is plotted on the cation triangle. The relative abundance of $\mathrm{Cl}^{-}, \mathrm{SO}_{4}{ }^{2-}$, and $\mathrm{HCO}_{3}$ - is plotted on the anion triangle (Fig. 6). The cation points on the triangular diagram are disposed in the small limited area. Anion points are located in a narrow area limited by a small fractional content of chloride ions and elongated in the direction of a changes the fraction content of bicarbonate ions. Long-term observation shows in anion composition bicarbonate ions dominates. According to the cation composition this water belongs to the calcium group. Thus, Selenge River has a bicarbonate -calcium composition. 


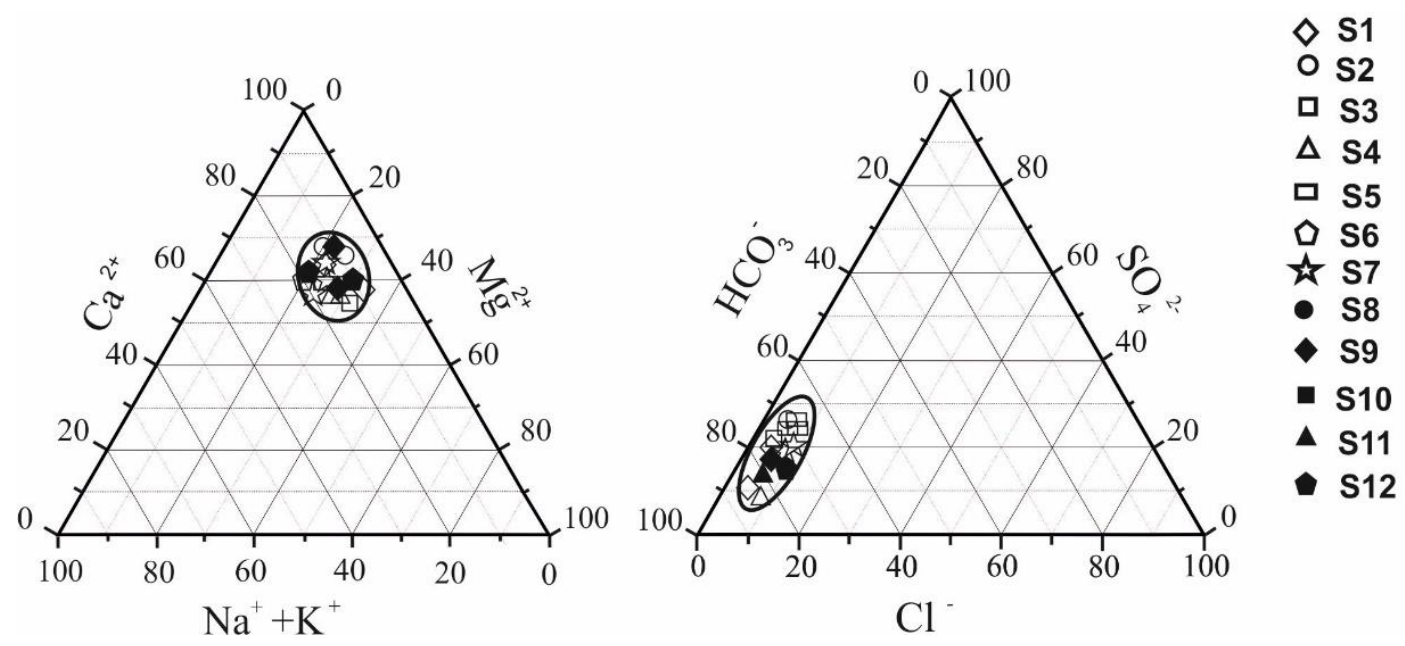

Figure 6. Ternary plots of the chemical composition of water Selenge River.

Anthropogenic impact on the ionic composition of river water are presented in downstream S12 in Table 3. By comparing data in Table, the level of anthropogenic influence on ionic composition can be assessed. It should be noted that in recent decades the content of sulphate increases from 8.6 $\%$ eq in 1950-1962 to $12-165 \%$ eq in 2000-2010. There is a general trend of increased content of $\mathrm{Na}^{+}$ and $\mathrm{Cl}$-ions in equivalent form during low-flow of river.

Table 3. Mean concentration major ions in Selenge River at sampling point S12 in different periods (numerator - $\mathrm{mg} \mathrm{l}^{-1}$, denominator $-\%$ eq).

\begin{tabular}{cccccccccc}
\hline $\begin{array}{c}\text { Observation } \\
\text { period }\end{array}$ & $\mathbf{H C O}_{3}$ & $\mathbf{S O}_{4}{ }^{2-}$ & $\mathbf{C l}^{-}$ & $\mathbf{C a}^{2+}$ & $\mathbf{M g}^{2+}$ & $\mathbf{N a}^{+}$ & $\mathbf{K}^{+}$ & $\mathbf{M}$ & $\begin{array}{c}\mathbf{Q} \\
\mathbf{m}^{3} \mathbf{s}^{-1}\end{array}$ \\
\hline \multirow{2}{*}{$1950-1962[\mathrm{]}$} & $\underline{88.7}$ & $\underline{6.5}$ & $\underline{1.23}$ & $\underline{20.7}$ & $\underline{4.6}$ & $\underline{4.1}$ & $\underline{1.1}$ & 127 & 872 \\
\hline \multirow{2}{*}{ July, 2004 } & $\underline{90.3}$ & $\underline{14.6}$ & $\underline{2.0}$ & $\underline{23.3}$ & $\underline{4.3}$ & $\underline{8.3}$ & $\underline{1.2}$ & 143 & 627 \\
\hline \multirow{2}{*}{ July, 2007 } & $\underline{83.6}$ & $\underline{10.2}$ & $\underline{3.0}$ & $\underline{20.5}$ & $\underline{5.1}$ & $\underline{5.5}$ & $\underline{1.2}$ & 128 & 486 \\
\hline
\end{tabular}

Trends in chemical composition of river water are affected by differences in rock composition and their distribution From the knowledge of the geology of the Selenge basin, chloride has no bedrock source in the region because there are no evaporites and $\mathrm{Cl}$ content in granitoid rocks is very low. Thus, we can assume that the $\mathrm{Cl}$ content in river waters is entirely coming from the atmosphere and anthropogenic impact.

For the Selenge River a significant fraction of $\mathrm{Na}$ and $\mathrm{Ca}$ can be attributed to chemical weathering of minerals constituting the soil and /or the parent rock of the basin. On Fig. 7 , element concentration ratios $\mathrm{Na} / \mathrm{Cl}$ vs $\mathrm{Ca} / \mathrm{Cl}$ and $\mathrm{Mg} / \mathrm{Na}$ vs $\mathrm{Ca} / \mathrm{Na}$ are presented. Concentration ratio $\mathrm{Na} / \mathrm{Cl}$ vary from 1 to 5 , whereas the ratio $\mathrm{Ca} / \mathrm{Cl}$ range from 5 to 21 . This is associated to main crystalline granitoids rocks bellong to calc-alkaline series. The $\mathrm{Ca} / \mathrm{Na}$ vs. $\mathrm{Mg} / \mathrm{Na}$ diagram shows that river water draining heterogeneity granitic rocks that this could be provided by calcite in relicts of large early ocean fragments of metamorphosed sediments. 

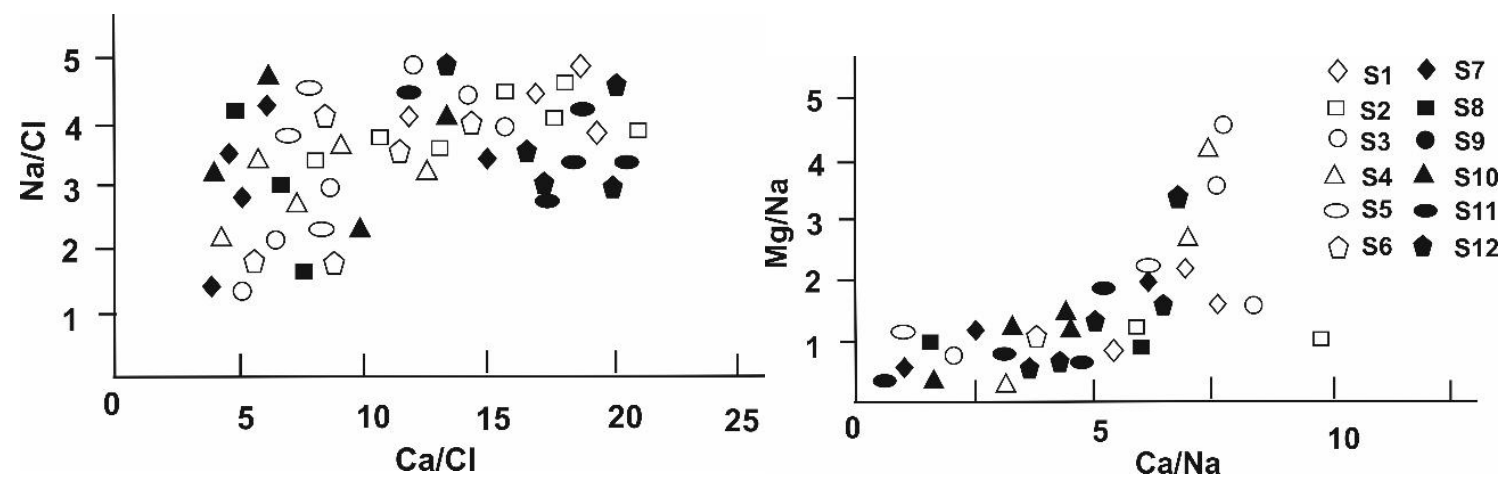

Figure 7. $\mathrm{Na} / \mathrm{Cl}$ vs $\mathrm{Ca} / \mathrm{Cl}$ and $\mathrm{Mg} / \mathrm{Na}$ vs $\mathrm{Ca} / \mathrm{Na}$ diagrams.

Organic and biogenic parameters of water quality of river are represented as follow. The highest DO level (11.68 $\left.\mathrm{mg} \mathrm{l}^{-1}\right)$ was found in December, the lowest level (6.8-7.1 $\left.\mathrm{mg} \mathrm{1}^{-1}\right)$ - in Febrary-March. The COD contents were found 7.3-24.0, relatively high in summer 17.8 -24.0 $\mathrm{mg} \mathrm{l}^{-}$, the BOD contents are $0.9-5.3 \mathrm{mg} \mathrm{l}^{-}$showed a similar trend. The concentration of TN $\left(0.05-0.81 \mathrm{mg} \mathrm{l}^{-1}\right), \mathrm{N}^{-} \mathrm{NH}_{4}(0.03-0.31$ $\left.\mathrm{mg} \mathrm{l}^{-1}\right)$ and TP (0.01-0.047 $\left.\mathrm{mg} \mathrm{l}^{-1}\right)$. The highest concentrations of Petro are 0.04-0.06 $\mathrm{mg} \mathrm{l}^{-1}, \mathrm{~V}$-phen are 0.003-0.005 $\mathrm{mg} \mathrm{l}^{-1}$.

\subsection{Trace elements}

Trace elements are characterized by concentrations lower than $1 \mathrm{mg} \mathrm{l}^{-1}$. This elements are much more fractionated by weathering, transport processes, and give information about distribution of pollution in surface waters.

Trace elements concentrations in river water at the some sampling sites are given in Table 4 . This data have been measured after filtration of the river sample using $0.45 \mu \mathrm{m}$ filters. Most of this data are presented information on natural levels of trace elements in water Selenge River. This mean value should be considered as a first-order approximation, because for the majority of elements its concentrations depends on the discharge of water. Concentrations of iron, aluminum, strontium and barium exceeds $10 \mu \mathrm{g} \mathrm{l}^{-1}$. The vast majority of trace elements have dissolved concentrations between

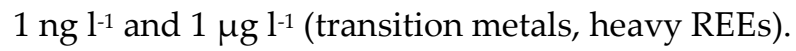

Table 4. Mean value of the dissolved trace elements at the sampling sites S6, S10, S12 and world average [14], $\mu \mathrm{g} \mathrm{l}^{-1}$.

\begin{tabular}{cccccccc}
\hline Elements & S6 & S10 & S12 & *WA & S6/WA & S10/ WA & S12/ WA \\
\hline $\mathrm{Li}$ & 2.96 & 2.53 & 2.73 & 1.84 & 1.61 & 0.93 & 1.48 \\
\hline $\mathrm{Be}$ & 0.015 & 0.029 & 0.031 & 0.009 & 1.73 & 0.92 & 3.50 \\
\hline $\mathrm{B}$ & 16 & 9.7 & 12.7 & 10.2 & 1.57 & 0.77 & 1.25 \\
\hline $\mathrm{Al}$ & 57 & 60 & 113 & 32 & 1.79 & 0.53 & 3.54 \\
\hline $\mathrm{Ti}$ & 3.98 & 3.35 & 5.4 & 0.44 & 8.13 & 0.62 & 11.09 \\
\hline $\mathrm{V}$ & 1.97 & 1.34 & 1.64 & 0.71 & 2.77 & 0.82 & 2.31 \\
\hline $\mathrm{Cr}$ & 1.25 & 0.88 & 2.02 & 0.70 & 1.79 & 0.44 & 2.88 \\
\hline $\mathrm{Mn}$ & 21 & 7.0 & 11.4 & 34.0 & 0.62 & 0.62 & 0.34 \\
\hline $\mathrm{Fe}$ & 126 & 171 & 220 & 66.0 & 1.91 & 0.78 & 3.33 \\
\hline $\mathrm{Co}$ & 0.10 & 0.087 & 0.15 & 0.148 & 0.70 & 0.59 & 0.99 \\
\hline $\mathrm{Ni}$ & 4.41 & 3.07 & 3.90 & 0.801 & 5.51 & 0.79 & 4.87 \\
\hline $\mathrm{Cu}$ & 3.76 & 2.64 & 3.48 & 1.48 & 2.54 & 0.76 & 2.35 \\
\hline $\mathrm{Zn}$ & 12.4 & 8.3 & 16 & 0.60 & 20.60 & 0.51 & 27.03 \\
\hline $\mathrm{As}$ & 1.19 & 0.89 & 1.54 & 0.62 & 1.92 & 0.57 & 2.49 \\
\hline $\mathrm{Se}$ & 0.091 & 0.059 & 0.055 & 0.07 & 1.31 & 1.08 & 0.78 \\
\hline
\end{tabular}




\begin{tabular}{|c|c|c|c|c|c|c|c|}
\hline $\mathrm{Rb}$ & 0.41 & 0.50 & 0.57 & 1.63 & 0.25 & 0.89 & 0.35 \\
\hline $\mathrm{Sr}$ & 182 & 119 & 114 & 60.0 & 3.03 & 1.05 & 1.90 \\
\hline $\mathrm{Y}$ & 0.27 & 0.48 & 0.45 & 0.04 & 6.79 & 1.07 & 11.27 \\
\hline $\mathrm{Zr}$ & 0.14 & 0.19 & 0.28 & 0.0390 & 3.66 & 0.66 & 7.27 \\
\hline $\mathrm{Nb}$ & 0.0069 & 0.0055 & 0.010 & 0.0017 & 4.05 & 0.54 & 5.95 \\
\hline Mo & 2.30 & 1.34 & 1.65 & 0.42 & 5.47 & 0.81 & 3.94 \\
\hline $\mathrm{Cd}$ & 0.46 & 0.24 & 1.93 & 0.08 & 5.80 & 0.13 & 24.07 \\
\hline Cs & 0.011 & 0.013 & 0.027 & 0.011 & 0.98 & 0.49 & 2.43 \\
\hline $\mathrm{Ba}$ & 23 & 16 & 20 & 23.0 & 1.02 & 0.78 & 0.88 \\
\hline $\mathrm{La}$ & 0.61 & 0.73 & 2.55 & 0.12 & 5.11 & 0.28 & 21.24 \\
\hline $\mathrm{Ce}$ & 0.54 & 0.75 & 1.21 & 0.2620 & 2.07 & 0.62 & 4.61 \\
\hline $\operatorname{Pr}$ & 0.080 & 0.15 & 0.17 & 0.04 & 2.01 & 0.92 & 4.19 \\
\hline $\mathrm{Nd}$ & 0.31 & 0.62 & 0.67 & 0.152 & 2.01 & 0.91 & 4.43 \\
\hline $\mathrm{Sm}$ & 0.061 & 0.13 & 0.14 & 0.036 & 1.70 & 0.93 & 3.77 \\
\hline $\mathrm{Eu}$ & 0.017 & 0.027 & 0.030 & 0.0098 & 1.71 & 0.90 & 3.08 \\
\hline $\mathrm{Tb}$ & 0.014 & 0.026 & 0.026 & 0.0055 & 2.46 & 1.03 & 4.69 \\
\hline $\mathrm{Gd}$ & 0.092 & 0.17 & 0.19 & 0.04 & 2.30 & 0.92 & 4.75 \\
\hline Dy & 0.068 & 0.13 & 0.15 & 0.03 & 2.25 & 0.91 & 4.94 \\
\hline Ho & 0.011 & 0.019 & 0.020 & 0.007 & 1.57 & 0.94 & 2.82 \\
\hline $\mathrm{Er}$ & 0.030 & 0.050 & 0.052 & 0.02 & 1.49 & 0.96 & 2.59 \\
\hline $\mathrm{Tm}$ & 0.0050 & 0.0075 & 0.0072 & 0.0033 & 1.53 & 1.05 & 2.17 \\
\hline $\mathrm{Yb}$ & 0.028 & 0.051 & 0.052 & 0.017 & 1.63 & 0.97 & 3.09 \\
\hline $\mathrm{Lu}$ & 0.0046 & 0.0086 & 0.0086 & 0.002 & 2.30 & 1.00 & 4.32 \\
\hline $\mathrm{Hf}$ & 0.0043 & 0.0063 & 0.010 & 0.006 & 0.72 & 0.63 & 1.67 \\
\hline $\mathrm{Ta}$ & 0.0004 & 0.0005 & 0.0008 & 0.0011 & 0.39 & 0.63 & 0.76 \\
\hline $\mathrm{W}$ & 0.29 & 0.35 & 0.29 & 0.1 & 2.95 & 1.20 & 2.90 \\
\hline $\mathrm{Pb}$ & 1.40 & 1.03 & 4.3 & 0.079 & 17.75 & 13.0 & 54.41 \\
\hline $\mathrm{U}$ & 1.86 & 1.18 & 1.01 & 0.372 & 5.00 & 1.18 & 2.70 \\
\hline
\end{tabular}

${ }^{*}$ WA - world average concentration for global river from Gaillardet et al. [14].

Dissolved concentrations of trace elements in Selenge river water are compared to the value of the world average. The results are summarized in Table 4. A rough classification of trace-element mobility in Selenge river water can be drawn. At the site S6 where is the interstate border the concentrations of of the majority of elements exceed the value world average by 1.3-20 times, including exceeding concentration of $\mathrm{Zn}, \mathrm{Pb}, \mathrm{Ti}, \mathrm{Y}, \mathrm{Ni}, \mathrm{Mo}, \mathrm{Cd}$, $\mathrm{La}$ by 20, 17, 8, 6, and higher than 5 times respectively. This is due to operational enterprices of mining and metallurgy industries and low discharge of river flow at the territory of Mongolia. In Russia at the site S10 downstream the sity Ulan-Ude significant exceeding is typical only for $\mathrm{Pb}$ by 13 times. In downstream of river the concentration of majority trace elements increase and exceed the value world average by 1.5-54 times. The most mobile elements includes $\mathrm{Pb}, \mathrm{Zn}, \mathrm{Cd}, \mathrm{La}, \mathrm{Ti}, \mathrm{Y}$ with mobility exceed the value world average by $54,27,24,21$ and near 11 times respectively.

The abundances of trace elements in river water depends both on their abundances in the rock of basin and their mobility during weathering and transport. The enhanced mobility of $\mathrm{Zn}, \mathrm{Pb}, \mathrm{Ti}, \mathrm{Y}$, $\mathrm{Ni}, \mathrm{Mo}, \mathrm{Cd}$, La must be due to the different weathering rates of bedrock-forming minerals. The enhanced concentrations of these marked elements in downstream are associated with the increase of water discharge. In contrary, dissolved trace concentrations are increase when the contents of major elements are low in downstream of the Selenge River.

Some insoluble elements $\mathrm{Al}, \mathrm{Fe}, \mathrm{REE}$, and Th exhibit a positive correlation with DOC. These elements were associated with organic material and show high variability, ranging from $60-80 \%$ for $\mathrm{Mn}, \mathrm{Rb}$ to $30-55 \%$ for DOC, iron, aluminum, REE. Major elements follow the reverse tendency. As can been on Fig.8, the concentrations of Fe in unfiltered water show a clear positive correlation with DOC. This is consistent with the higher proportion of particulate matter. 
The dissolved concentrations of $\mathrm{Al}$ and $\mathrm{Fe}$ show a positive correlation. The Fe/ $\mathrm{Al}$ ratio varies in narrow range 2.2-2.7, it may be concluded that these two elements do not fractionate. At the same time this ratio indicate a preferential Fe mobility. Two different processes can account for this result. First is the remobilization of iron in the form of $\mathrm{Fe}^{2+}$ in reduced conditions arising from the decay of organic matter. The second process concerns aluminum precipitation in the form of new-formed kaolinite, also gibbsite during kaolinite dissolution. Another observations concerns La, REE, which shows the positive correlation with Al.

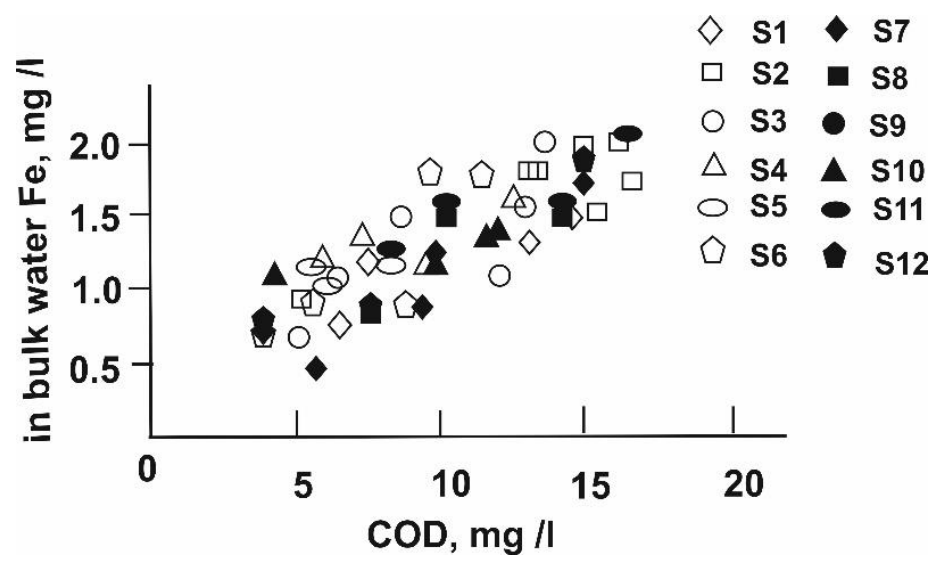

Figure 8. Fe vs. DOC relationships in Selenge River.

The data obtained was used for to assess the effects of mining, manufacturing and other influences from anthropogenic activities. Table 5 shows the comparison of normative and average values of the concentration of heavy metals in river water. The main polluting substances were iron, manganese, and zinc. Concentration of heavy metals in river water was 2.1- 4.3 times higher than maximum allowable concentration for Selenga River. Thus, assessment of the water Selenge River testifies to the fact that they do not meet the requirements of the bodies used for fishing.

The pollution is aggravated by the penetration of a large amount of pollutants, washed by the precipitation from the mineral waste banks of mining enterprices, dumps of production wastes (in particular, copper-molybdenum and integrated iron-and-steel works in the cities of Erdenet and Darkhan) and also discharged into the atmosphere by the industrial enterprices. Agricultural lands and more than of ploughed land is subject to deflation and water erosion. The main function of the forests of Lake Baikal and Selenge River Basin is the reproduction of pure water. So, forestry management should be aimed at the conservation, natural forest regeneration, including fire protection, and the protection against harmful organisms, and disease.

Table 5. Dissolved concentration of heavy metal in Selenga river water in summer (mean value), $\mu \mathrm{g}$ $1^{-1}$.

\begin{tabular}{ccccccccccc}
\hline $\begin{array}{c}\text { Sample } \\
\text { point }\end{array}$ & $\mathrm{Cr}$ & $\mathbf{M n}$ & $\mathrm{Fe}$ & $\mathrm{Co}$ & $\mathbf{N i}$ & $\mathbf{C u}$ & $\mathrm{Zn}$ & $\mathrm{As}$ & $\mathrm{Cd}$ & $\mathbf{P b}$ \\
\hline S1 & 0.62 & 8.7 & 225 & 0.16 & 2.3 & 2.6 & 18.3 & 1.57 & 0.05 & 1.3 \\
\hline S2 & 0.59 & 9.2 & 212 & 0.12 & 1.6 & 2.5 & 17.6 & 0.92 & 0.06 & 0.9 \\
\hline S3 & 0.81 & 11.3 & 237 & 0.19 & 1.8 & 2.8 & 16.2 & 0.84 & 0.07 & 1.1 \\
\hline S4 & 0.95 & 11.4 & 204 & 0.24 & 2.1 & 3.7 & 19.6 & 0.74 & 0.09 & 1.8 \\
\hline S5 & 1.03 & 14.6 & 227 & 0.19 & 3.5 & 4.3 & 23.4 & 0.98 & 0.12 & 1.4 \\
\hline S6 & 0.98 & 21.8 & 241 & 0.16 & 2.3 & 3.9 & 21.4 & 1.03 & 0.08 & 1.2 \\
\hline S7 & 0.85 & 18.6 & 218 & 0.18 & 1.6 & 3.8 & 18.3 & 1.42 & 0.01 & 0.5 \\
\hline S8 & 0.75 & 12.5 & 182 & 0.21 & 3.7 & 3.6 & 12.6 & 1.53 & 0.02 & 0.8 \\
\hline S9 & 0.84 & 10.6 & 173 & 0.19 & 4.3 & 2.9 & 10.4 & 0.91 & 0.01 & 0.7 \\
\hline S10 & 0.87 & 9.2 & 192 & 0.15 & 3.2 & 2.9 & 15.3 & 1.07 & 0.09 & 0.9 \\
\hline S11 & 0.92 & 9.8 & 198 & 0.15 & 2.9 & 3.2 & 14.6 & 1.12 & 034 & 1.5 \\
\hline S12 & 1.09 & 12.4 & 208 & 0.14 & 3.1 & 3.8 & 16.7 & 1.28 & 0.76 & 4.3 \\
\hline MAC* & 1 & 10 & 100 & 1 & 10 & 1 & 10 & 10 & 5 & 10 \\
\hline Excess & $\mathrm{B}$ & 2.1 & 2.4 & $\mathrm{~B}$ & $\mathrm{~B}$ & 4.3 & 2.3 & $\mathrm{~B}$ & $\mathrm{~B}$ & $\mathrm{~B}$ \\
MAC & & & & & & & & & & \\
\hline
\end{tabular}


$\mathrm{MAC}^{*}$ - Maximum Allowable Concentration, B - below MAC.

\subsection{REE}

The best examples of decoupling between major ions and trace elements in Selenge River come from the REE. In our cases, dissolved REE concentrations increase when the concentrations of major ions are low. For long-average observation at the sampling site $\mathrm{S} 6$ river water have high $\mathrm{pH}$ between 7.9-8.6 and alkalinity, being much influenced by carbonate dissolution, exhibit highest mineralization than at the sites S10 and S12. The lowest concentrations of REEs in river water are found at the site S6. This is illustrated on the Fig. 9.

The samples of water at sites S6 are characterized by deeper negative $\mathrm{Ce}$ anomalies $\left(\mathrm{Ce} / \mathrm{Ce}^{*}=\right.$ $0.49-0.50)$ than at the site $\mathrm{S} 12\left(\mathrm{Ce} / \mathrm{Ce}^{*}=0.30-0.32\right)$. At the sites S10-S12 samples have slightly negative Eu anomalies $\left(\mathrm{Eu} / \mathrm{Eu}^{*}=0.78-0.80\right)$, but samples of the site $\mathrm{S} 6$ show a low or lack negative Eu anomalies $\left(\mathrm{Eu} / \mathrm{Eu}^{*}=0.93-0.94\right)$. In the Selenge water LREE dominate over HREE. The samples of water (sites S6 and S12) are enriched by LREE relative to HREE with $(\mathrm{La} / \mathrm{Yb})_{\mathrm{N}}=2.14-4.71$, whereas at the sampling site $\mathrm{S} 10$ the ratio $(\mathrm{La} / \mathrm{Yb})_{\mathrm{N}}=1.34-1.37$.

The knowledge of the geology of the Selenge basin show that the rocks in Transbaikalia enriched in LREE relative to HREE, $(\mathrm{La} / \mathrm{Yb}) \mathrm{N}=8-23$ and their Eu anomalies (either negative or positive) are poorly pronounced or are not pronounced at all $\left(\mathrm{Eu} / \mathrm{Eu}^{*} 0.67-1.22\right)$ [8]. This literature data illustrates that the syenites, alkaline and peralkaline granites, basic and felsic volcanics are sources of REE in Selenge River water.

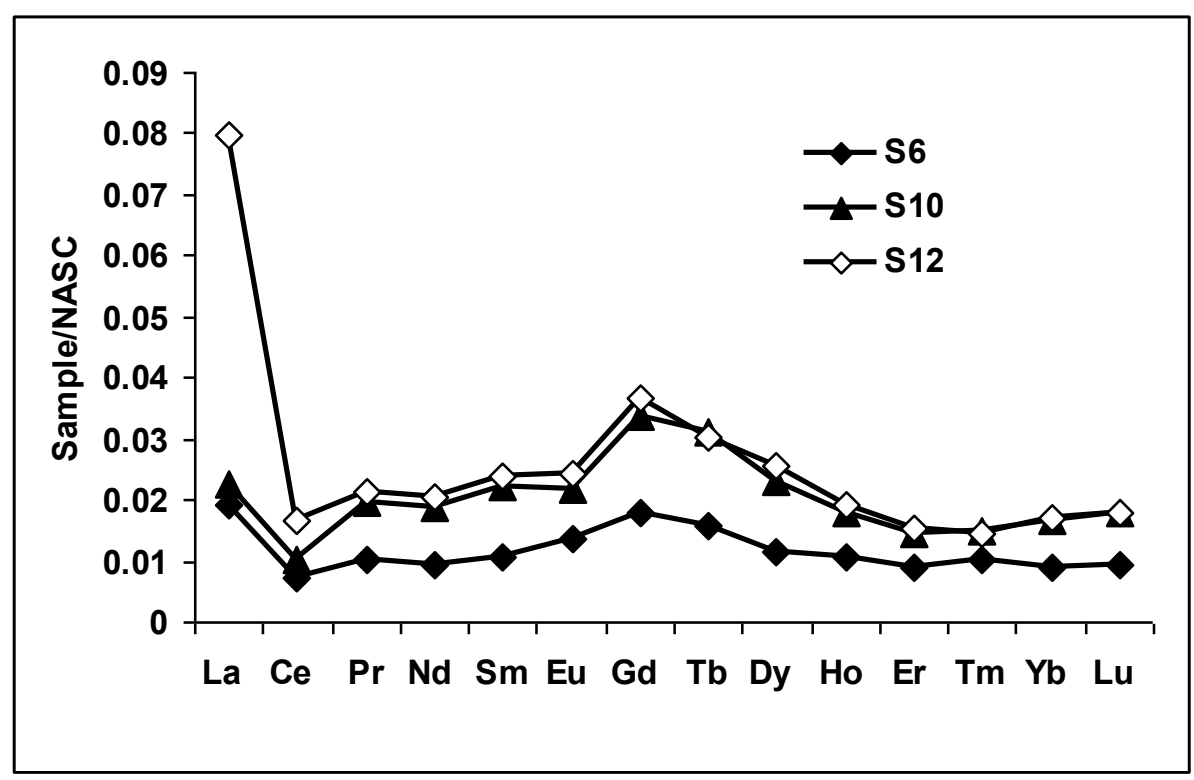

Figure 9. NASC-normalized REE patterns of Selenge River at sites S6, S10 and S12.

\section{Conclusions}

Selenge River is a transboundary river, which rises in Mongolia and flows into the Lake Baikal in Russia (the Republic of Buryatia). In the Mongolia territory climate aridity increases, precipitation decreases, discharge of water small, sometimes saline soils enrich the water with minerals. In Russia discharge of water increase by 2-3 times, that leads to the formation of lowly mineralized water. Mean intra-annually mineralization decrease from 200 to $152.8 \mathrm{mg} \mathrm{l}^{-1}$ along the river.

(1) Selenge River has a bicarbonate -calcium composition. Long-term observation shows in anion composition bicarbonate ions dominates. The cation composition belongs to the calcium group. The major cations are in decreasing order as $\mathrm{Ca}^{2+}>\mathrm{Mg}^{2+}>\mathrm{Na}^{+}+\mathrm{K}^{+}$and major anions are also in decreasing order as $\mathrm{HCO}_{3}>\mathrm{SO}_{4}{ }^{2-}>\mathrm{Cl}^{-}$. In recent decades the content of sulphate increases from 8.6 $\%$ eq in 1950-1962 to $12-165 \%$ eq in 2000-2010. There is a general trend of increased content of $\mathrm{Na}^{+}$ and $\mathrm{Cl}$-ions in equivalent form during low-flow of river. 
(2) Concentrations of iron, aluminum, strontium and barium exceeds $10 \mu \mathrm{g}^{-1}$. The vast majority of trace elements have dissolved concentrations between $1 \mathrm{ng} \mathrm{l}^{-1}$ and $1 \mu \mathrm{g} \mathrm{l}^{-1}$ (transition metals, heavy REEs). The most mobile elements in Selenge River includes $\mathrm{Pb}, \mathrm{Zn}, \mathrm{Cd}, \mathrm{La}, \mathrm{Ti}, \mathrm{Y}$ with mobility exceed the value world average by 54, 27, 24, 21 and near 11 times respectively. When compared with MAC (Maximum Allowable Concentration) for the heavy metals the main polluting substances were iron, manganese, and zinc. Concentration of heavy metals in river water was 2.1- 4.3 times higher than MAC for Selenga River.

(3) For long-average observation the lowest concentrations of REEs are found at the high $\mathrm{pH}$ and alkalinity, the highest - in downstream of river. Normalized distribution of REEs are characterized by deeper negative $\mathrm{Ce}$ anomalies $\mathrm{Ce} / \mathrm{Ce}^{*}=0.49-0.50$, slightly negative $\mathrm{Eu}$ anomalies $\mathrm{Eu} / \mathrm{Eu}^{*}=0.78$ 0.80. In the Selenge water LREE dominate over HREE with the ratio $(\mathrm{La} / \mathrm{Yb})_{\mathrm{N}}=1.34-1.37$.

Finding: This study was performed within the state tasks of GIN SB RAS. The investigations has been conducted within the fundamental research framework of the GIN SB RAS (reg. number AAAA-A17-117021310076-3). This work was financially supported by Grant from Russian Foundation for Basic Research (Siberia), project no. 1845-030003 (principal investigator A.M. Plyusnin).

Author Contributions: Z.I.K. wrote the text of the article, conducted research as well as in editing and translating the text. A.M. P. assisted in research and providing funding. V.V.D. assisted in research and sample preparation.

Conflicts of Interest: The authors declare no conflict of interest.

\section{References}

1. Yuri Mun, Ick Hwan Ko, Lunten Janchivdorj, Bair Gomboev, Sang InKang, Chang-Hee Lee. 2008. Integrated water management. Model on the Selenge River basin. Status survey and investigation (Phase I).- Seoul: Korea Environment Institute. 2008. 423 p.

2. Khazheeva Z.I., Plyusnin A.M. 2012. Modern water management in the river basin. Selenga and its influence on the ecological state of watercourses. Geography and natural resources 4. p. 48-52.

3. Khazheeva Z.I. 2014.Resources and chemical composition of water, suspended solids and bottom sediments of the rivers Selenga basin. Ulan-Ude. $376 \mathrm{p}$.

4. Tomurtogoo O., Windley B.F., Kröner A., Badarch G., Liu D.Y., 2005. Zircon age and occurrence of the Adaatsag ophiolite and Muron shear zone, central Mongolia: constraints on the evolution of the MongolOkhotsk ocean, suture and orogen. Journal of the Geological Society 162, 125-134.

5. Yarmolyak V.V., Kovalenko V.I. 2003. Batholiths and geodynamics of their formation in the central Asian fold belt. Russian Geology and Geophysics 44(12), p. 1305-1320.

6. Sengör A.M.C., Natal'in B.A., 1996. Palaeotectonics of Asia: fragments of a synthesis. In: Yin A., Harrison T.M. (Eds.), The Tectonic Evolution of Asia. Cambridge University Press, Cambridge, pp. 486-640.

7. Windley B.F., Alexeiev D., Xiao W., Kröner A., Badarch G., 2007. Tectonic models for accretion of the Central Asian Orogenic Belt. Journal of the Geological Society 164, 31-47.

8. Tsygankov A.A., Litvinovsky B.A., Jahn B.M., Reichow M.K., Liu D.Y., Larionov A.N., Presnyakov S.L., Lepekhina Ye.N., Sergeev S.A., 2010. Sequence of magmatic events in the Late Paleozoic of Transbaikalia, Russia (U-Pb isotope data). Russian Geology and Geophysics 51 (9), 972-994.

9. Jahn B.M., Litvinovsky B.A., Zanvilevich A.N., Reichow M. 2009. Peralkaline granitoid magmatism in the Mongolian-Transbaikalian Belt: evolution, petrogenesis and tectonic significance. Lithos 113, 521-539.

10. Yarmolyak V.V., Kovalenko V.I. et al. 2008. The age of the Khangai batholith and the problem of batholith formation in Central Asia. Doklady Earth Sciences 423 (1), 1223-1228

11. Yarmolyak V.V., Kovalenko V.I., Sal'nikova E.B., Budnikov S.V., Kovach V.P., Kotov A.B., Ponomarchuk V.A. 2002.Tectono-magmatic zoning, magma sources, and geodynamic of the Early Mesozoic MongoliaTransbaikal province. Geotectonics 36(4), 293-311.

12. Barbarin B.A. 1999. Review of the relationships between granitoid types, their origins and their geodynamic environments, Litos 46, 605-626.

13. Khazheeva Z.I., Plyusnin A.M. 2016.Variations in climatic and hydrological parameters in the Selenga River basin in the Russian Federation. Russian Meteorology and Hydrology. 41(9). p. 640-647.

14. Gaillardet J., Viers J., Dupre B. 2003.Treatise on Geochemistry. Trace elements in river waters. Berlin: Elsevier Ltdю5(9). p. 225-272. 
(C) 2020 by the authors; licensee MDPI, Basel, Switzerland. This article is an open access article distributed under the terms and conditions of the Creative Commons by Attribution (CC-BY) license (http://creativecommons.org/licenses/by/4.0/). 